\title{
Conceptualizing Programme Evaluation
}

\author{
Salochana Hassan, Ph.D., Cape Peninsula University of Technology, South Africa
}

\begin{abstract}
The main thrust of this paper deals with the conceptualization of theory-driven evaluation pertaining to a tutor training programme. Conceptualization of evaluation, in this case, is an integration between a conceptualization model as well as a theoretical framework in the form of activity theory. Existing examples of frameworks of programme evaluation from the literature have been conjugated to yield a conceptualization model for the evaluation of the tutor training programme at the Cape Peninsula University of Technology in South Africa. In order to take the study to a higher level of deep analysis, this paper argues for the application of activity theory in the research design and subsequent data collection and analysis. Since evaluation can be a daunting and complex task, the adoption of theory was intended to provide a fulcrum for the study and therefore, this paper argues, becomes an integral part of evaluation. In addition, the application of activity theory in programme evaluation has not been well explored elsewhere and therefore, this paper transcends this limitation by making a case for the use of activity theory in programme evaluation, in particular, tutor training programmes.
\end{abstract}

Keywords: Programme Evaluation; Theory-Driven Evaluation; Tutor Training Programme; Activity Theory; Conceptualization Model for Evaluation.

\section{INTRODUCTION}

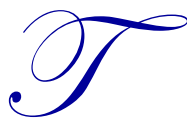

he advantages of tutorials in improving the teaching and learning experience of tutees are well documented. In the midst of the challenges faced by lecturers who have to cope with large classes, tutorials provide a mechanism of enhancing deep learning in small groups (Hanley (1996; Underhill and McDonald 2010). Bruffee (1993) claims that tutors can engage in a conversation with tutees and provide support in translating the terms of the communities they are trying to enter so that they may incorporate the practices of that group. Tutors themselves stand to benefit from the tutor-tutee relationship. Tutors may learn by teaching (Topping 1998) while developing and enhancing communication, interpersonal and organizational skills (Falchikov 2001). Undoubtedly, these skills do not come naturally to tutors and therefore, tutor training programmes play a pivotal role in training and developing tutors.

The main purpose of this paper is to propose a conceptualization model for evaluation of a tutor training programme as well as a theoretical framework, namely critical theory, for the design of the study. In particular, second and third generation activity theory (Engeström 2001) guides the discussions of the activity systems of a tutor training programme. The application of activity theory in conceptualizing the evaluation of tutor training programmes is sparse and therefore this paper addresses an important gap in the literature on programme evaluation.

The context of the study is the Cape Peninsula University of Technology (CPUT) in South Africa, where the tutor training programme is dichotomized into a centralized and decentralized model with the former being managed by Fundani: Centre for Higher Education Development and the latter by the respective Faculties, in particular the Faculty of Engineering. To date, a comparison of the two models at CPUT has not been undertaken.

\section{LITERATURE BACKGROUND ON TYPES OF EVALUATION STUDIES AND THEIR PURPOSES}

Arguably, programme evaluation poses several challenges not least of which is the complexity and enormous scope of the exercise. In order to obtain a deeper insight into the purpose and types of evaluation and the 
approaches adopted by other researchers, an exploration of the relevant literature was deemed to be a good starting point. A poignant question at this stage was: Why evaluate in the first place?

A response to this question was sought from Patton (1997) who offers three main reasons for undertaking an evaluation, namely; 1) To make a judgment, 2) For improvement and 3) To generate knowledge. Judgmentorientated evaluations are intended to determine the effectiveness and success of the programme and to what extent the objectives and goals have been achieved. Improvement-orientated evaluations are intended to establish the programme's strength and weaknesses and whether the programme has been implemented properly or not, so as to enhance the quality of the programme. Knowledge-orientated evaluations focus on an understanding of how programmes work and how people change their attitudes and behavior because of successful interventions.

The primary focus of the evaluation described in this paper is improvement-orientated and is, therefore, formative in that the study seeks to determine how the tutor training programme can be improved. Patton (1996) argues that evaluation should be broadly conceptualized as a knowledge-generating activity and that it is too "rich and varied" to be compartmentalized into a "single dichotomy". Therefore, the secondary focus of the evaluation will be knowledge-orientated as part of a comparative study between the centralized and de-centralized models.

Rossi and Freeman 1993 provide a three-pronged description of the types of evaluation studies (see table 1) which encompasses conceptualization, monitoring and effectiveness of a programme. The evaluation study conceptualized within this paper encompasses all three types of evaluation illustrated in table 1.

\section{Table 1: Types Of Evaluation Studies}

\begin{tabular}{|l|l|}
\hline \multicolumn{1}{|c|}{ Type } & \multicolumn{1}{c|}{ Purpose } \\
\hline $\begin{array}{l}\text { Conceptualization and design of } \\
\text { interventions }\end{array}$ & $\begin{array}{l}\text { Focuses on whether a programme is designed in such a way that it addresses identified } \\
\text { needs adequately. }\end{array}$ \\
\hline $\begin{array}{l}\text { Monitoring of programme } \\
\text { implementation }\end{array}$ & $\begin{array}{l}\text { To determine whether the programme has been implemented properly and whether the } \\
\text { programme provides evidence within a context of accountability. }\end{array}$ \\
\hline $\begin{array}{l}\text { Assessment of programme } \\
\text { effectiveness }\end{array}$ & Establishes the degree to which a programme produces the desired outcome. \\
\hline
\end{tabular}

Other authors such as Posavac and Carey (1992) support the monitoring of programme implementation as shown in table 1, by their take on "evaluation of process". Patton (2002), on the other hand, argues for utilizationfocused evaluation which is based on the principle that evaluation should be judged by its utility and actual use. The implication for evaluators is that the evaluation process and design of any evaluation should be done with consideration of how everything that is done will ultimately affect $u s e$.

A further investigation of the relevant literature yielded additional guidance in terms of how evaluation can be approached. For example, programme evaluation approaches as synthesized by Fitzpatrick, Saners and Worthen (2004) are encapsulated as follows:

- Objectives-orientated approach which emphasizes the explicit statement of programme goals, objectives and the extent to which they have been met (Tyler 1991).

- $\quad$ Expertise-orientated approach is one where the evaluator relies on his/her judgment about the worth of the object of evaluation.

- $\quad$ Participant-orientated approach places emphasis on the needs of the progamme participants.

- $\quad$ Empowerment evaluation involves the participants in the evaluation process (Fetterman 2002).

The different approaches show that different assumptions are made about how research on evaluation should be addressed (Ross 2010). Broadly speaking, however, much of the literature on programme evaluation gives a general, simplistic understanding of how evaluation should be conducted. What is required is a conceptualization of the evaluation study that would offer evaluators the tools for analysis. This article draws on existing models to propose a conceptualization model that would be applicable for evaluation of a tutor training programme. 


\section{A CONCEPTUALIZATION MODEL FOR PROGRAMME EVALUATION}

Mouton and Babbie (2001) advise that evaluation requires a frame of reference in order to guide the collection of data and interpretation of empirical findings. Taking cognisance of this, this paper draws on aspects of the following frameworks and model:

- $\quad$ The RUFDATA framework which stands for the following elements: Reasons and purposes, Uses, Focus, Data and evidence, Audience, Timing and Agency (Saunders 2000).

- Winberg's ( 2011) levels of analysis in evaluations, namely: 1) an analysis of the conceptual core of the programme, 2) its design, 3) factors affecting its implementation, and 4) its outcomes.

- Jacobs's (2000) model for the evaluation of educational innovation.

For the purposes of conceptualizing a model for the evaluation described in this paper, the aforementioned frameworks and model have been adapted and integrated to yield the following conceptualization model:

Contextualization of the programme.

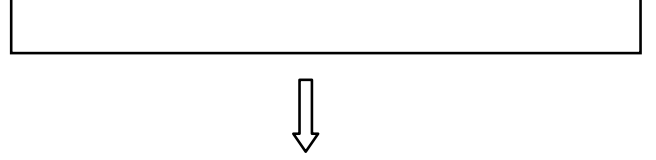

Goals of the evaluation. Reasons.

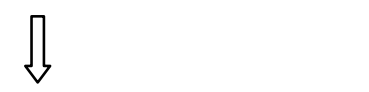

Aspects of the programme to be evaluated. Focus.

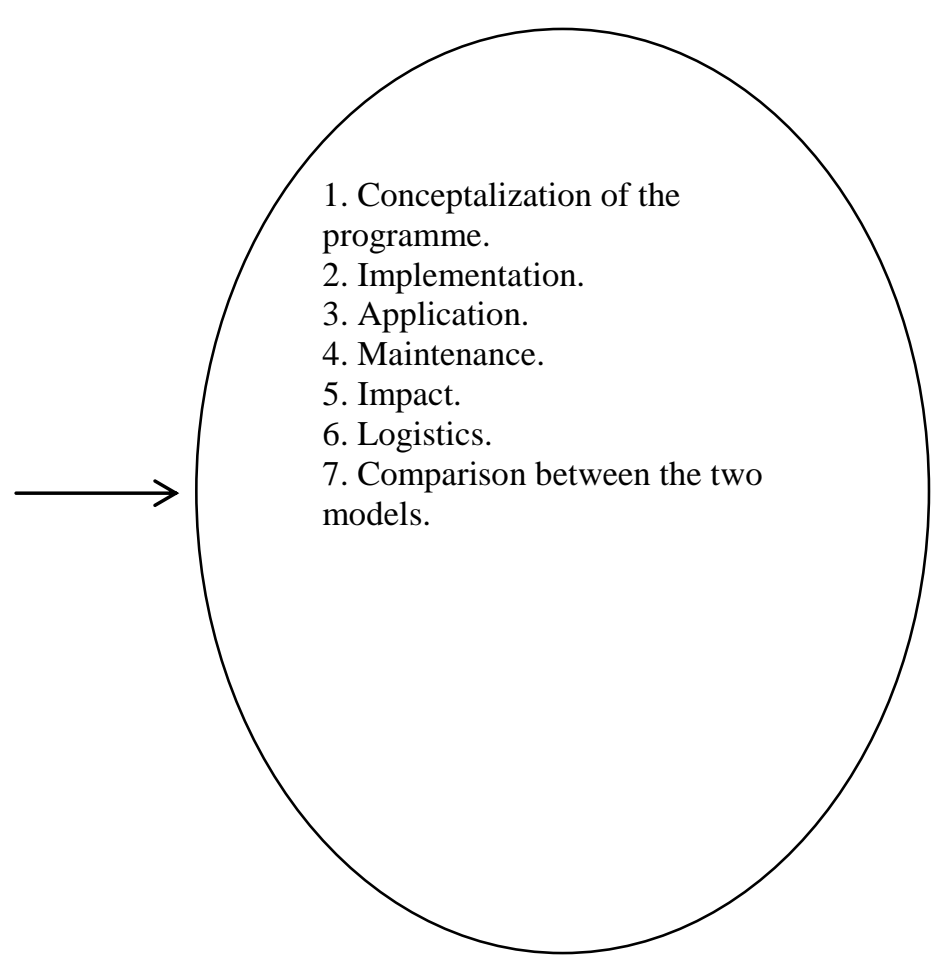

Research design for evaluation: Sources of information. Methods of data. collection and analysis. Data and time.

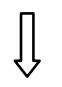

Outcome: Dissemination of findings.

Audience. Uses.

Figure 1. A Model For The Evaluation Of The Tutor Training Programme (An Adaptation Of The Frameworks Of Winberg (2011), Saunders (2000) And Jacobs's (2000) Model) 


\section{THEORY-DRIVEN PROGRAMME EVALUATION USING ACTIVITY THEORY}

The conceptualization model shown in figure 1 was framed by critical theory to render the evaluation theory-driven. The advantage of applying theory in evaluations can be gleaned from the literature. For example, Chen (1990) states that theory provides guidelines for analyzing a phenomenon as well as for understanding the significance of research findings. Programme theory also clarifies the link between the operational features of a programme and its effects. An important point of departure in theory-driven evaluation is to make the programme theory explicit (Renger 2010). This section of the paper attempts to achieve that through a discussion on how activity theory is applied in the design of an evaluation study of a tutor training programme.

Activity theory proposes a very specific notion of context in that the activity itself is the context. What takes place in an activity system which is composed of object, actions, and operation, is the context. Context is created through an activity involving people and artifacts. Context is neither an outer container nor shell inside of which people behave in certain ways. Rather, context is both internal to people-involving specific objects and goals - and, at the same time, external to people, involving artifacts, other people and specific settings (Nardi 1996).

The importance of contextualization for evaluation of a programme is further portrayed in the statement made by Chen (1990:45): "The worthiness of a programme is difficult to judge without having information on the contextual and/or intervening factors that help to make that programme a success or failure". In addition, Ross (2010:489) contends that "context evaluation encompasses identifying the target population and the needs or problems to be addressed". In this paper, the historical background and context of the two models for the tutor training programme is an important point of departure for the evaluation study.

For Engeström (2001), activity theory is underpinned by five principles: 1) The first principle is that the unit of activity is mediated through tools or artifacts and is object orientated, that is, focused on a goal or purpose; 2) The second principle is the multi-voic-edness of activity systems in that the division of labour creates different positions for participants; 3 ) The third principle refers to historicity because activity systems take shape and get transformed over lengthy periods of time. For example, the history of the theoretical ideas and tools that have shaped the activity; 4) The fourth principle is the central role of contradictions as the point of departure for change and development, and 5) The fifth principle anticipates expansive learning and the dialectical resolutions of contradictions. The fourth and fifth principles are the mechanisms though which activity systems transform and are closely aligned with the concept of "expansive learning". "Expansive learning activity produces culturally new patterns of activity" (Engeström 2001:139). These principles have been taken into account in the design of the research questions for the evaluation study as discussed later in this paper.

First generation activity theory was introduced by Vygotsky in response to the defects of stimulus-response behaviourism. He argued that human behaviour is not simply prompted by stimuli but is mediated through artifacts (Bakhurst 2009). Activity theory as developed by Engeström $(1987 ; 1996)$ takes the object-oriented, tool mediated collective activity system as its unit of analysis, thereby bridging the divide between the subject and the societal structure (Daniels 2001) and therefore, second generation activity theory distinguishes between "action" and "activity". An action is conducted by an individual/group to achieve a particular goal. An "activity" is undertaken by a community and has an "object" and a "motive". Thus, action is individual while activity is collective. Third generation activity theory examines the relations between activity systems and addresses issues of representations, voice, emotion, identity and difference (Bakhurst 2009).

This paper discusses the application of second and third generation activity theory. Second generation activity theory is applied in evaluating the application of the tutor training programme; the subject is the tutor, the object is enhancement of learning among tutees and the tools or artifacts are the course materials and teaching and learning methods (figure 2). Kuutti (1991) explains that a key idea in activity theory is the notion of mediation by artifacts which carry with them a particular culture and history stretching across activities through time and space. The community consists of multiple individuals or subgroups who share the same general object (Engeström 2001). In this paper, they are the tutors, tutees, link lecturers and lecturers. The rules are departmental policies on tutorials and conventions that constrain actions. The division of labour looks at the role of each member in the community 
of practice and refers to horizontal division of tasks between members and the vertical division of power and status (Engeström 2001).

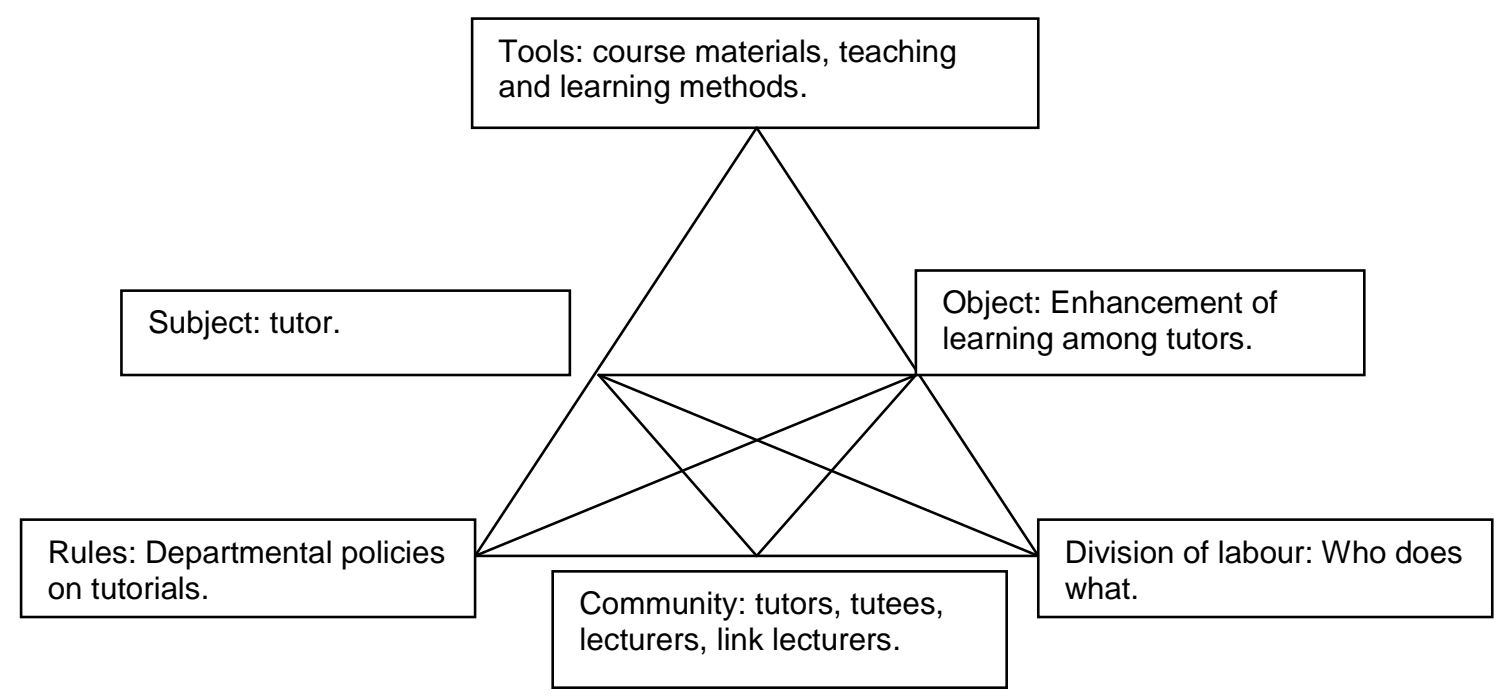

Figure 2. Second Generation Activity System Showing The Components Of The Application Of Tutor Training

Third generation activity theory allows people from different activity systems to work together as the object starts to interact; in the process expansive learning is produced (Engeström 2001). The notions of 'knotworking, coconfiguration and boundary crossing" are realized when activity systems interact (Avis 2009). According to Kuutti (1991) activities may overlap in that different subjects engaged together in a set of coordinated actions may have multiple or conflicting objects. In both the centralized and de-centralized models of the tutor-training programme, within the context of this paper, there is a common object, that is, training of tutors, which opens up possibilities of expansive learning. The subjects are the tutor training co-ordinators while the tools are the teaching and learning methods and materials. The community comprises the tutors and tutor-training co-ordinators. The rules refer to policies for tutor training and the division of labour pertains to what each person is responsible for doing.

For Vygotsky (1978) humans use tools to change the world and are themselves transformed through tool use. The study described in this paper focuses on the transformation that takes place in the identities of the tutors as they shift from being students to being collaborative members of the teaching community. Tutors have to adjust their identity to the new situation they find themselves in when they start to tutor students. By developing their own expertise through tutor training programmes, tutors can make a difference to the learning that happens in the classroom.

\section{RESEARCH DESIGN}

An integration of the conceptualization model given in figure 1 as well as the aspects of activity theory discussed above was applied in compiling a framework for the evaluation study shown in table 2. The framework contains a focus of the evaluation aligned with the relevant questions and the accompanying research methodology. 
Table 2. Framework For Evaluation Of The Tutor Training Programmes

Within The Centralized (Fundani:CHED) And Decentralized Models (Faculty Of Engineering).

\begin{tabular}{|c|c|c|}
\hline Focus of evaluation & Research questions & Research methodology \\
\hline Contextualization & $\begin{array}{l}\text { What is the historical nature and comparative context of the two } \\
\text { models? Why have we ended up with these models and what can } \\
\text { we do to improve them? }\end{array}$ & $\begin{array}{l}\text { Document analysis; semi- } \\
\text { structured face-to-face } \\
\text { interviews. }\end{array}$ \\
\hline Conceptualization & $\begin{array}{l}\text { What are the aims and objectives of the programmes in both } \\
\text { models? What is the conceptual understanding of tutor training } \\
\text { within the two models? Is the programme conceptualized and } \\
\text { designed in such a way that it addresses the real needs of the } \\
\text { intended beneficiaries? }\end{array}$ & $\begin{array}{l}\text { Document analysis; } \\
\text { observation of tutor training } \\
\text { programmes; semi } \\
\text { structured interviews. }\end{array}$ \\
\hline $\begin{array}{l}\text { Implementation. Roles, } \\
\text { division of labour of tutor } \\
\text { training coordinators, } \\
\text { link lectures and tutors }\end{array}$ & $\begin{array}{l}\text { Has the programme been properly implemented and managed? } \\
\text { What kind of training is being offered? What teaching and } \\
\text { learning methods are adopted and what course materials are } \\
\text { being used? What tools are being used in the training and are } \\
\text { they appropriate in achieving the outcome? What are the roles of } \\
\text { the tutor training coordinators, tutors and link lecturers? }\end{array}$ & $\begin{array}{l}\text { Observation of tutor training } \\
\text { programmes; semi } \\
\text { structured interviews. }\end{array}$ \\
\hline $\begin{array}{l}\text { Application. Roles, } \\
\text { division of labour of } \\
\text { tutors, tutees and } \\
\text { lecturers }\end{array}$ & $\begin{array}{l}\text { How do tutors support the learning of tutees? What are the roles } \\
\text { of the tutors, tutees and lecturers? What are the relative positions } \\
\text { of power between tutors, tutees and lecturers? }\end{array}$ & $\begin{array}{l}\text { Observation of tutorials } \\
\text { facilitated by tutors. } \\
\text { Interviews; self } \\
\text { administered questionnaires. }\end{array}$ \\
\hline Maintenance & $\begin{array}{l}\text { What support (formal and non-formal) is there for tutors? What } \\
\text { systems do we have administratively and academically to support } \\
\text { these tutors? }\end{array}$ & $\begin{array}{l}\text { Self administered } \\
\text { questionnaires. }\end{array}$ \\
\hline Impact /outcome & $\begin{array}{l}\text { Have the outcomes been achieved? To what degree was the } \\
\text { programme implemented as planned? To what degree did the } \\
\text { programme accomplish its intended outcomes, that is, } \\
\text { improvement in the capacity of tutors and tutees? Does the } \\
\text { programme serve the target group? What is the impact of tutor } \\
\text { support on the quality of tutees' learning? What are the } \\
\text { perceptions of tutors and tutees regarding tutor training } \\
\text { programmes and tutorials respectively? }\end{array}$ & $\begin{array}{l}\text { Self administered } \\
\text { questionnaires. }\end{array}$ \\
\hline $\begin{array}{l}\text { Logistical and } \\
\text { administrative matters }\end{array}$ & $\begin{array}{l}\text { Is the necessary infrastructure in place to support programme } \\
\text { implementation? Were the programme outcomes obtained in the } \\
\text { most cost-efficient manner? Are funds spent for the intended } \\
\text { purpose? What are the logistical constraints of the tutor training } \\
\text { programme? (For example, funding, selection and appointment } \\
\text { of tutors, record keeping). }\end{array}$ & Face-to-face interviews. \\
\hline Community of practice & $\begin{array}{l}\text { Who is the community that is involved in the activity system? Do } \\
\text { programme coordinators, tutors, link lecturers, lecturers and } \\
\text { tutees work as a team? }\end{array}$ & Face-to-face interviews. \\
\hline Rules & $\begin{array}{l}\text { Is tutor training and implementation in line with policy? What is } \\
\text { the academic culture within which the tutor training programme } \\
\text { is implemented and applied? What are the administrative rules? } \\
\text { What are the selection criteria and admission requirements for } \\
\text { tutors? }\end{array}$ & $\begin{array}{l}\text { Document analysis, face-to- } \\
\text { face interviews. }\end{array}$ \\
\hline
\end{tabular}

The research approach described in this study employs qualitative and quantitative methods and focuses predominantly on document analysis, observation, face-to-face, semi-structured interviews and the administration of questionnaires.

Quantitative methods provide representations of outcomes that can be utilized to gage accomplishments against goals, standards or targets. Qualitative data would be useful in providing rich narrative information which could be applied to assess phenomena that cannot be collected when quantitative methods are used (McConney and Maor 2009). The triangulation of methods and data will allow for multiple perspectives of the research problem. 
According to Kushner (2000) interviews will also help relay the narratives of key participants and would contribute towards personalizing the evaluation process.

From the interviews, data will be recorded, transcribed and then analysed using coding, categorization and the identification of themes. Interviews will allow respondents to provide clarity with respect to their responses. Self-administered questionnaires will be designed using a Likert scale and the data gathered will be statistically analysed. Self-administered questionnaires will allow for more respondents to be involved in the study and make data collection relatively easy.

A purposive sample will be drawn of respondents who will be involved in the study. A research sample that are likely to have the necessary knowledge of tutor training and are able to reflect meaningfully on the scope of the study will be drawn (see Morse 1994).

\section{CONCLUSION}

The position taken in this article is that tutor training programmes are activity systems which are objectorientated and mediated through tools. Within each activity system are interconnecting relationships between the subject, the object, tools, rules, community of practice, and division of labour (Engeström, 1999) as they relate to components of the tutor training programme. In essence, within the activity system, tutors undergo transformation from being students to becoming members of a community within the academe. Further, the intersection of the objects of third generation activity systems of both the centralized and de-centralized tutor training programmes at the Cape Peninsula University of Technology provides a mechanism for expansive learning (Engeström 2001) to emerge. This theoretical framing has provided a basis for programme evaluation and will be employed in conjunction with a conceptualization model for evaluation, as part of a quality assurance initiative.

\section{AUTHOR INFORMATION}

Salochana Hassan, Ph.D., Cape Peninsula University of Technology, South Africa. The author currently works in the area of academic staff development. In particular, she has extensive experience in the field of academic staff development and has facilitated numerous workshops pertaining to innovative methods of teaching and learning, and assessment. She has also developed and co-ordinates the Teaching Development Programme for new academic staff at the CPUT.

She has presented several conference papers and posters at national and international level in the field of problembased learning (PBL), outcomes-based education, research-based learning, quality assurance, policy development, academic staff development, medical education and science education. She has also published journal articles on PBL and academic staff development. Salochana Hassan, Ph.D., Cape Peninsula University of Technology, Center for Higher Education Development, PO Box 652, Cape Town, South Africa. E-mail: HassanL@cput.ac.za

\section{REFERENCES}

1. Avis, J. (2009). Transformation or transformism: Engstrom's version of activity theory. Educational Review, 61(2), 151-165.

2. Bakhurst, D. (2009). Reflections on activity theory. Educational Review, 61(2), 197-210.

3. Bruffee, K. (1993). Collaborative learning, higher education, interdependence and the authority of knowledge. Baltimore, MD: John's Hopkins University Press.

4. Chen, H. (1990). Theory-driven evaluations. Sage publications; California.

5. Daniels, H. (2001). Vygotsky and pedagogy. New York: Routledge.

6. Engeström, Y. (1987). Learning by expanding: An activity theoretical approach to developmental research. Helsinki, Orienta-Konsultit Oy.

7. Engeström, Y. (1996). Perspectives on activity theory. Cambridge: Cambridge University Press.

8. Engeström, Y. (1999). Activity theory and individual and social transformation. In Y. Engeström, R. Miettinen, and R. Punamäki (Eds, Perspectives on activity theory, (pp 19-38). Cambridge: Cambridge University Press. 
9. Engeström, Y. (2001). Expansive learning at work: Toward an activity theoretical re-conceptualization. Journal of Education and Work, 14(1), 133-156.

10. Falchikov, N. (2001). Learning together. Peer tutoring in higher education, London: Routledge Falmer.

11. Fetterman, D. M. (2002). Empowerment evaluation: Building communities of practice and a culture of learning. American Journal of Community Psychology, 30(1), 89-102

12. Fitzpatrick, J. L., Saners, J. R., \& Worthen, B. R. (2004). Program evaluation: Alternatives, approaches, and practical guidelines ( ${ }^{\text {rd }}$ ed.). Boston: Pearson Education Inc.

13. Hanley, P. (1996). Mentor development in a university orientation programme: The first James Cook experience. Proceedings of the $2^{\text {nd }}$ Pacific Rim Conference on the First year in Higher Education, Transition to Active Learning, Ormond College, University of Melbourne, 3-5 July:243-247.

14. Jacobs, C. (2000). The evaluation of educational innovation. Evaluation, 6(3), 261-280.

15. Kushner, S. (2000). Personalizing evaluation. London: Sage.

16. Kuutti, K. (1991). Activity theory and its applications to information systems research and development. In H.E. Nissen (Ed.), Information Systems Research, (pp. 529-549). Amsterdam: Elsevier Science Publishers.

17. McConney, A. \& Maor, D. (2009). The evaluation of a pilot mentoring programme for beginner science and maths teachers: Summative project evaluation report. School of Education. Murdoch University. Perth Western Australia.

18. Morse, J.M. (1994). Designing funded qualitative research. In N.K. Denzin \& Y.S. Lincoln (Eds.). Handbook of qualitative research, Thousand Oaks, California: Sage Publications.

19. Mouton, J. \& Babbie, E. (2001). The practice of social research, Cape Town: Oxford University Press.

20. Nardi, B.A. (1996). Studying context: A comparison of activity theory, situated action models and disctributed cognition. In B.A. Nardi (Ed.), Context and consciousness: a theory and human computer interaction, (pp. 35-52). Cambridge, MA: MIT Press.

21. Patton, M. Q. (1996). A world larger than formative and summative. Evaluation Practice, 17(2), 331-345.

22. Patton, M.Q. (1997). Utilization-focussed evaluation. $3^{\text {rd }}$ Ed. Thousand Oak, CA; Sage Publications.

23. Patton, M. (2002). Utilization-focussed evaluation. Evaluation in education and human services, 49, 425438.

24. Posavac, E.J. \& Carey, R.G. (1992). Program evaluation: methods and case studies. Engelwood Cliffs: Prentice Hall.

25. Renger, R. (2010). Constructing and verifying programme theory using source documentation. Canadian Journal of Programme Evaluation, 25(1), 51-67.

26. Ross, M.E. (2010). Designing and using programme evaluation as a tool for reform. Journal of Research on Leadership Education, 5(12.7), 481-506.

27. Rossi, P.H. and Freeman, H.E. (1993). Evaluation: A systematic approach. Newbury Park, CA: Sage.

28. Saunders, M. (2000) Beginning an evaluation with RUFDATA: theorising a practical approach to evaluation planning. Evaluation, 6(1), 7-21.

29. Topping, K. (1998). The effectiveness of peer tutoring in further and higher education: A typology and review of the literature. In S. Goodlad (Ed.), Students as tutors and mentors, London: Kogan Page.

30. Tyler, R. W. (1991). General statement on program evaluation. In M. W. McLaughlin \& D. C. Phillips (Eds.), Evaluation and education: At quarter century (pp. 1-2). Chicago: The University of Chicago Press.

31. Underhill, J. \& McDonald, J. (2010). Collaborative tutor development: Enabling a transformative paradigm in a South African University. Mentoring and Tutoring: partnership in Learning, 18(2), 91-106.

32. Vygotsky, L.S. (1978). Mind in society: Development of higher psychological processes. Ed. M. Cole, V. John-Steiner, S. Scribner and E. Souberman (ed. and trans.). Cambridge, MA: Harvard University Press.

33. Winberg, C. (2011). The elephant in the room: evaluating postgraduate research in higher education. In M. Saunders, P. Trowler \& V. Bamber (Eds.), Reconceptualizing evaluation in higher education, Berhshire: Society for Research into Higher Education and Open University Press. 